\title{
The francoeuriae species group in the genus Alloclita Staudinger, 1859 with description of $A$. canariensis Koster \& Junnilainen, sp. nov. from the Canary Islands (Lepidoptera, Gelechioidea, Cosmopterigidae)
}

\author{
SJaAk (J.C.) Koster ${ }^{1}$, Per Falck ${ }^{2}$, Jari Junnilainen ${ }^{3}$, \\ Ole Karsholt $^{4}$, ERIK J. van NiEUKERKEN ${ }^{1}$ \\ 1 Naturalis Biodiversity Center, PO Box 9557, NL-2300 RA Leiden, The Netherlands; sjaak.koster@naturalis.nl; \\ nieukerken@naturalis.nl \\ 2 Aarsdalevej,22,DK-3730 Neksø,Denmark; per.falck@live.dk \\ 3 Finnish Museum of Natural History, Zoology Unit, P.O.Box 17, FI-00014 University of Helsinki, Finland; junnilainen. \\ jari@googlemail.com \\ 4 Zoologisk Museum, Natural History Museum of Denmark, Universitetsparken, 15, DK-2100 Copenhagen, Denmark; \\ okarsholt@snm.ku.dk
}

http://zoobank.org/54FD00FB-207F-49DA-99AF-68A689C3F0B5

Received 12 November 2019; accepted 6 February 2020; published: 14 April 2020

Subject Editor: Vazrick Nazari.

\begin{abstract}
Alloclita canariensis Koster \& Junnilainen sp. nov. is described from the Canary Islands Fuerteventura, Gran Canaria, Lanzarote and Tenerife. Two specimens from Gran Canaria were previously misidentified as A. francoeuriae Walsingham, 1905, a North African species. We record A. francoeuriae also as new for the Canary Islands, from Fuerteventura. The potential hostplants of A. canariensis are Asteriscus species (Asteraceae). DNA barcodes of both species are provided and compared with five other Alloclita species. The related Alloclita subitariella (Riedl, 1993), only known from the holotype from Saudi Arabia, is redescribed. These three species are placed in the new Alloclita francoeuriae group.
\end{abstract}

\section{Introduction}

The genus Alloclita Staudinger, 1859 (Cosmopterigidae, Gelechioidea) comprises small to medium sized moths with broad fore and hindwings. The forewing pattern varies from rather dull and uncoloured to a more striking pattern with contrasting fasciae. The genus was established by Staudinger (1859) as a monotypic genus for $A$. recisella Staudinger, 1859, from Spain. The second species recognised was $A$. francoeuriae Walsingham, 1905, described on the basis of 27 male and one female specimens from Algeria. It is the only species for which the biology of the larva has been described. Larvae were found on Pulicaria undulata (L.) C.A.Mey (Asteraceae, as Francoeuria crispa (Forsk.) Cass.) (Walsingham 1905).

The genus Alloclita is rather small, with 16 currently named species (Sinev 2002). Its distribution is restricted to the Old World with half the species occurring in the Palaearctic Region, five in the Afrotropical region and three in the Oriental region (Sinev 2002). In the Palaearctic region the 
distribution is restricted to the Mediterranean area, including Northern Africa, and the Middle East. The species are found in dry and desert-like areas and the males, especially, are attracted to light. Females are rare among collected material and only known for seven species.

From Macaronesia, the Canary Islands are probably among the best explored islands for Microlepidoptera. So far, 17 species of Cosmopterigidae in eight genera have been recorded, five of which are endemic (Koster and Sinev 2017). Since then Alloclita francoeuriae was recorded as new for the islands, from Gran Canaria, on the basis of two old male specimens collected in Agaete in 1930 and 1931 (Vives Moreno and Gastón 2017).

Since 2014 Danish and Finnish lepidopterists have collected a large series of Alloclita specimens from the larger islands Fuerteventura, Gran Canaria, Lanzarote and Tenerife, in total more than 100 specimens.

Although the specimens show variation in wingspan and forewing coloration, there was no doubt that most of this material belongs to an unknown species in the genus Alloclita. Dissection of the male and female genitalia showed that this species is closely related to A. francoeuriae. After comparing these data with the figures of the adult and the male genitalia of the specimens identified as A. francoeuriae by Vives Moreno and Gastón (2017), we conclude that their material is conspecific with the new Alloclita-species.

Alloclita francoeuriae, A. canariensis sp. nov. and also a third species from Saudi Arabia, A. subitariella (Riedl, 1993), are closely related and differ from all other species in the genus by the longer and narrower forewings. In the male genitalia they differ by the valvae and by the basal lobes of the valvae, both are much shorter and slightly asymmetrical. These parts of the male genitalia are symmetrical in the other species of Alloclita.

Since the three species look similar to each other both externally and in male genitalia, all three species are treated here, a new species group is erected, the francoeuriae group, and the differences in the forewing pattern and the genitalia are discussed and illustrated. As a consequence the other Alloclita species are placed in the A. recisella group.

\section{Material and methods}

\section{Material}

Danish collectors (Per Falck, Carsten Hviid, Ole Karsholt, Knud Larsen, Bjarne Skule) attracted almost all specimens to an 8 watt super actinic light. A few specimens from Lajares on Fuerteventura were obtained by netting in the afternoon sunshine. Material collected by Jari Junnilainen originated from a single locality in Gran Canaria. The moths were collected there by a combination of car lights, a head lamp and a small ultraviolet tube lamp of 4 watts, powered by regular batteries.

We only recognize specimens of the new species as paratypes when they have been studied for the description, the other specimens listed were later identified by the co-authors (see International Commission on Zoological Nomenclature 1999, art. 72.1.1). The "Material Examined" section follows the fine grained formatting guidelines as advocated in the new "Author Guidelines", to ensure accurate conversion of the records to XML and consequent indexing for GBIF and other platforms. We provide decimal coordinates, derived from Google Earth or obtained from the collectors, for specimens collected by B. Skule et al. calculated from the DMS data on the labels. 


\section{Morphology}

Genitalia were dissected following the methodology presented by Brown (1997) and Robinson (1976). The wings and the male genitalia were stained with phenosafranin. In older slides eosin was also used and unsclerotized parts of the female genitalia were stained with Chlorazol black.

The morphological terminology follows Hodges (1978, 1998), Koster and Sinev (2003) and Koster (2016).

\section{Illustrations}

The photographs of adult Alloclita canariensis and A. francoeuriae were taken by EvN with a Zeiss AxioCam digital camera attached to a motorized Zeiss SteREO Discovery V20, using Carl Zeiss AxioVision 4.9.1 software. The adult of A. subitariella was depicted in watercolours. Wing venation, male and female genitalia were illustrated in line drawings, in lateral position for the males and in ventral position for the male and female genitalia of $A$. francoeuriae and A. canariensis; these drawings have been reduced to $70 \%$ of their original size. Drawings of the genitalia were made with a compound microscope using the camera lucida method. For this purpose a strong light source (slide projector) was used for the illumination on the mirror of the microscope. A prism was placed on top of the microscope eyepiece to bend the projection $90^{\circ}$ and project the subject on drawing paper. All outlines were drawn by pencil and later set in Indian ink. Scale bars alongside the drawings are $0.1 \mathrm{~mm}$ (Koster 2019). The watercolour and the line drawings were made by JCK.

The distribution maps were prepared with ArcGIS software 10.2.2.

\section{DNA extraction and sequencing}

DNA barcodes were derived in the laboratories of the Naturalis Biodiversity Center from extracts taken from abdomens following the procedures outlined by van Nieukerken et al. (2012) and Doorenweerd et al. (2015). Abdomens and genitalia were taken from the lysis and prepared by JCK in the standard way. Barcoded specimens all received a RMNH.INS. registry number, whether the specimen is in the RMNH collection or not. Remaining extracts are stored in the Naturalis extraction collection.

The resulting COI sequences are combined with other available Alloclita barcodes, in total representing seven species from West Africa, Middle East and East Asia, in the public BOLD dataset "Alloclita from the Canary Islands [DS-ALLOCAN]" [https://doi.org/10.5883/DS-ALLOCAN]. All data and GenBank registry numbers can be found in this dataset.

The Neighbor Joining tree was prepared with the tree building tools on BOLD (Ratnasingham and Hebert 2007), using the Kimura 2 Parameter distance model, and edited with Adobe Illustrator.

\section{Depositories}

$\begin{array}{ll}\text { CF } & \text { Collection Per Falck. } \\ \text { CJ } & \text { Collection Jari Junnilainen. } \\ \text { NHMB } & \text { Naturhistorisches Museum, Basel, Switzerland. } \\ \text { NHMUK } & \text { Natural History Museum, London, UK. } \\ \text { RMNH } & \text { Naturalis Biodiversity Center, Leiden, The Netherlands. } \\ \text { ZIN } & \text { Zoological Institute, Academy of Sciences, St. Petersburg, Russia. } \\ \text { ZMUC } & \text { Zoological Museum, Natural History Museum of Denmark. }\end{array}$




\section{Taxonomy}

\section{Alloclita canariensis Koster \& Junnilainen, sp. nov.} http://zoobank.org/F9C7EE3A-C864-443D-8493-1B7FF4455D77

Figs 1-3, 6, 11, 14-18

[Alloclita francoeuriae; Vives Moreno and Gastón 2017: 320. Misidentification]

Material examined. Holotype. SPAIN - Canary Islands • $\delta^{7}$; Tenerife, Tamaimo; $28.27^{\circ} \mathrm{N}, 16.82^{\circ} \mathrm{W} ; 550 \mathrm{~m}$; 8-22 Nov. 2016; Per Falck leg.; genitalia slide: JCK 8685; DNA barcode sample COSM066-18; ZMUC; RMNH.INS.15578.

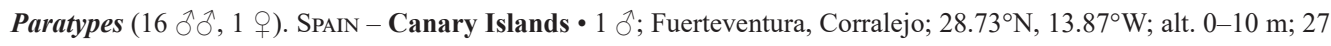
Feb.-19.Mar. 2018; P. Falck leg.; CF・ 1 §; Fuerteventura, Lajares; $28.68^{\circ} \mathrm{N}, 13.94^{\circ} \mathrm{W}$; alt. 50-80 m; 1-27 Nov. 2017; P. Falck leg.; CF $\bullet 1$; same locality as preceding; 27 Feb.-19 Mar. 2018; P. Falk leg.; CF 1 o ; same data as preceding; genitalia slide: JCK 8686; DNA barcode sample COSM067-18; RMNH; RMNH.INS.15579 • 1 đ; Gran Canaria, Ayacata; $27.966^{\circ} \mathrm{N}, 15.606^{\circ} \mathrm{W}$; alt. $1500 \mathrm{~m}$; 17-30 Sep. 2018; P. Falck leg.; genitalia slide: JCK 8687, DNA barcode sample

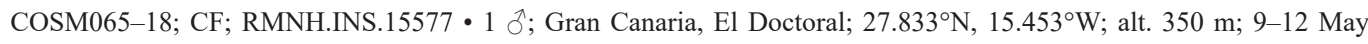

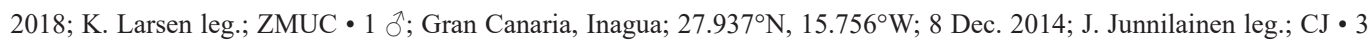

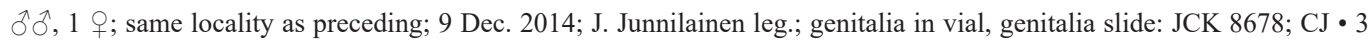

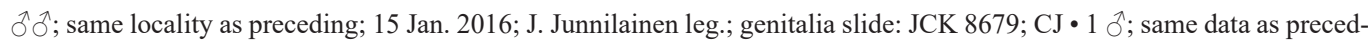
ing; genitalia slide: JCK 8675, DNA barcode sample COSM064-18; RMNH; RMNH.INS.15554 • 1 §ै; Gran Canaria, 1.3 km N Mogan; $27.89583^{\circ} \mathrm{N}, 15.7225^{\circ} \mathrm{W}$; alt. $430 \mathrm{~m}$; 3-8 Nov. 2014; B. Skule leg; ZMUC • $1 \overbrace{}^{\curvearrowright}$; Tenerife, Arona; $28.10^{\circ} \mathrm{N}$, $16.68^{\circ} \mathrm{W}$; alt. $500 \mathrm{~m}$; 8-22 Nov. 2016; P. Falck leg.; wing slide: JCK 8690; CF.

Additional material $\left(97 \hat{\partial} \partial, 10\right.$ 우). SPAIN - Canary Islands $\cdot 1 \hat{\delta}$; Fuerteventura, Betancuria; $28.425^{\circ} \mathrm{N}$, $14.057^{\circ} \mathrm{W}$; alt. $400 \mathrm{~m} ; 7-27$ Nov. 2017; P. Falck leg.; $\mathrm{CF} \bullet 1 \mathrm{\delta}^{\mathrm{j}}$; Fuerteventura, Corralejo; $28.73^{\circ} \mathrm{N}, 13.87^{\circ} \mathrm{W}$; alt. $0-10$

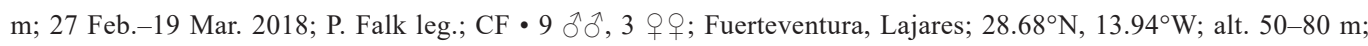
1-27 Nov. 2017; P. Falck leg.; CF • 20 $\widehat{\partial}, 1$ ค; same locality as preceding; 27 Feb.-19 Mar. 2018; P. Falk leg.; CF

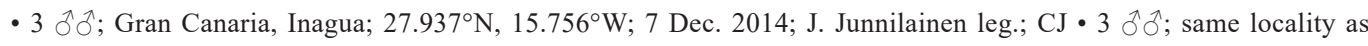

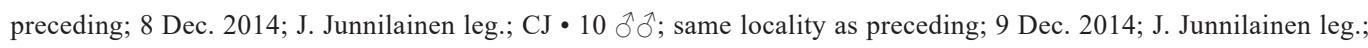

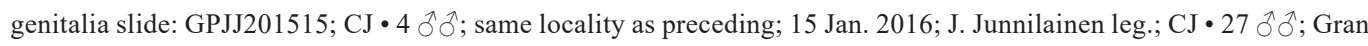
Canaria, $1.3 \mathrm{~km} \mathrm{~N}$ Mogan; $27.89583^{\circ} \mathrm{N}, 15.7225^{\circ} \mathrm{W}$; alt. $430 \mathrm{~m}$; $3-8$ Nov. 2014; B. Skule leg.; genitalia slide: Karsholt

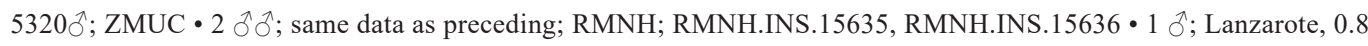
km S Conil; $1,4 \mathrm{~km} \mathrm{~N}$ Tias; $28.96055^{\circ} \mathrm{N}, 13.66536^{\circ} \mathrm{W}$; alt. $240 \mathrm{~m}$; $2-8$ Nov. 2018; B. Skule \& C. Hviid leg.; ZMUC - 2 วิำ, 2 우; Lanzarote, El Bosquecillo; $29.12618^{\circ} \mathrm{N}, 13.52211^{\circ} \mathrm{W}$; alt. 600 m; 6 Nov. 2018; B. Skule \& C. Hviid

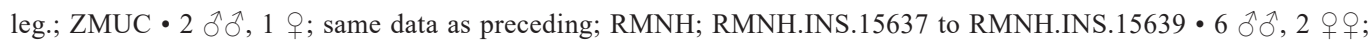
Lanzarote, Urb. Famara; ; 29. $09669^{\circ}$ N , 13. $55479^{\circ}$ W; alt. 55 m; $2-8$ Nov. 2018; B. Skule \& C. Hviid leg.; ZMUC • 4 §ð; Lanzarote, 2 km SW Urb. Famara, Las Laderas; $29.09669^{\circ} \mathrm{N}, 13.55479^{\circ} \mathrm{W}$; alt. $75 \mathrm{~m}$; 2-8 Nov. 2018; B. Skule \& C. Hviid leg.; ZMUC • $2 \widehat{\partial^{\lambda}} \widehat{\partial}, 1$; ; Lanzarote, $3,5 \mathrm{~km} \mathrm{NE}$ Teguise, Barranco de Manguia; $29.07089^{\circ} \mathrm{N}, 13.52647^{\circ} \mathrm{W}$; alt. 275 m; 4 Nov. 2018; B. Skule \& C. Hviid leg.; ZMUC • 2 đo ; Tenerife, Arona; $28.10^{\circ} \mathrm{N}, 16.68^{\circ} \mathrm{W}$; alt. $500 \mathrm{~m}$; 8-22 Nov. 2016; P. Falck leg.; CF.

Additional literature records ( $2 \hat{\partial} \hat{\partial}$, Vives Moreno and Gastón 2017). SPAIN - Canary Islands $\bullet 1 \hat{\delta}$; Gran Canaria, Agaete; $28.1^{\circ} \mathrm{N}, 15.7^{\circ} \mathrm{W}$; alt. $43 \mathrm{~m}$; 23 Oct. 1930 ; A. Cabrera leg.; genitalia slide: $61293 \mathrm{AV} \bullet 1$ $\widehat{\delta}$; same locality data as preceding; 17 Oct. 1931. 

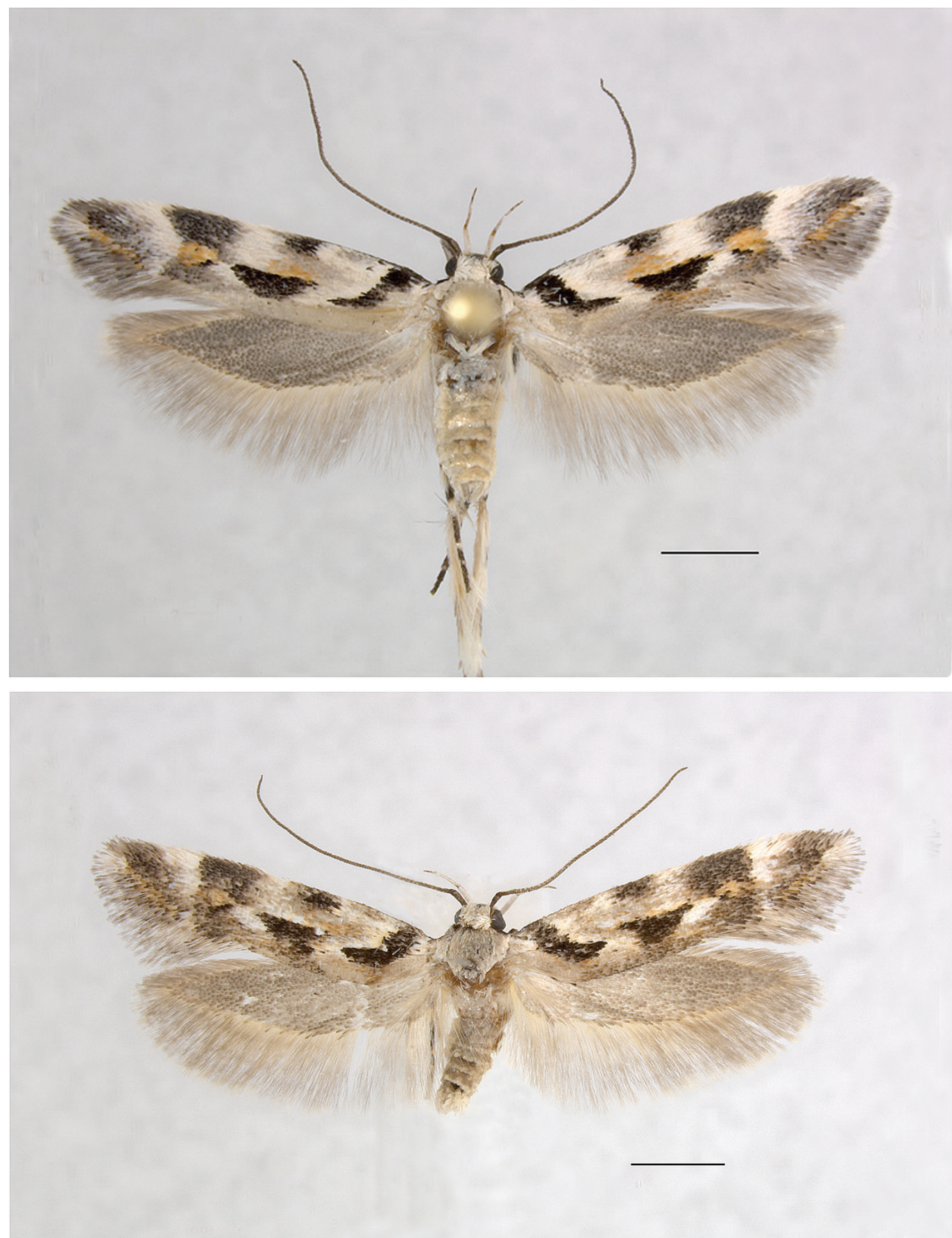

Figures 1, 2. Alloclita canariensis sp. nov., male habitus. 1 Paratype, Gran Canaria, Ayacata, RMNH. INS.15577. 2 Holotype, Tenerife, Tamaimo, RMNH.INS 15578. Scale bars: 2 mm. 

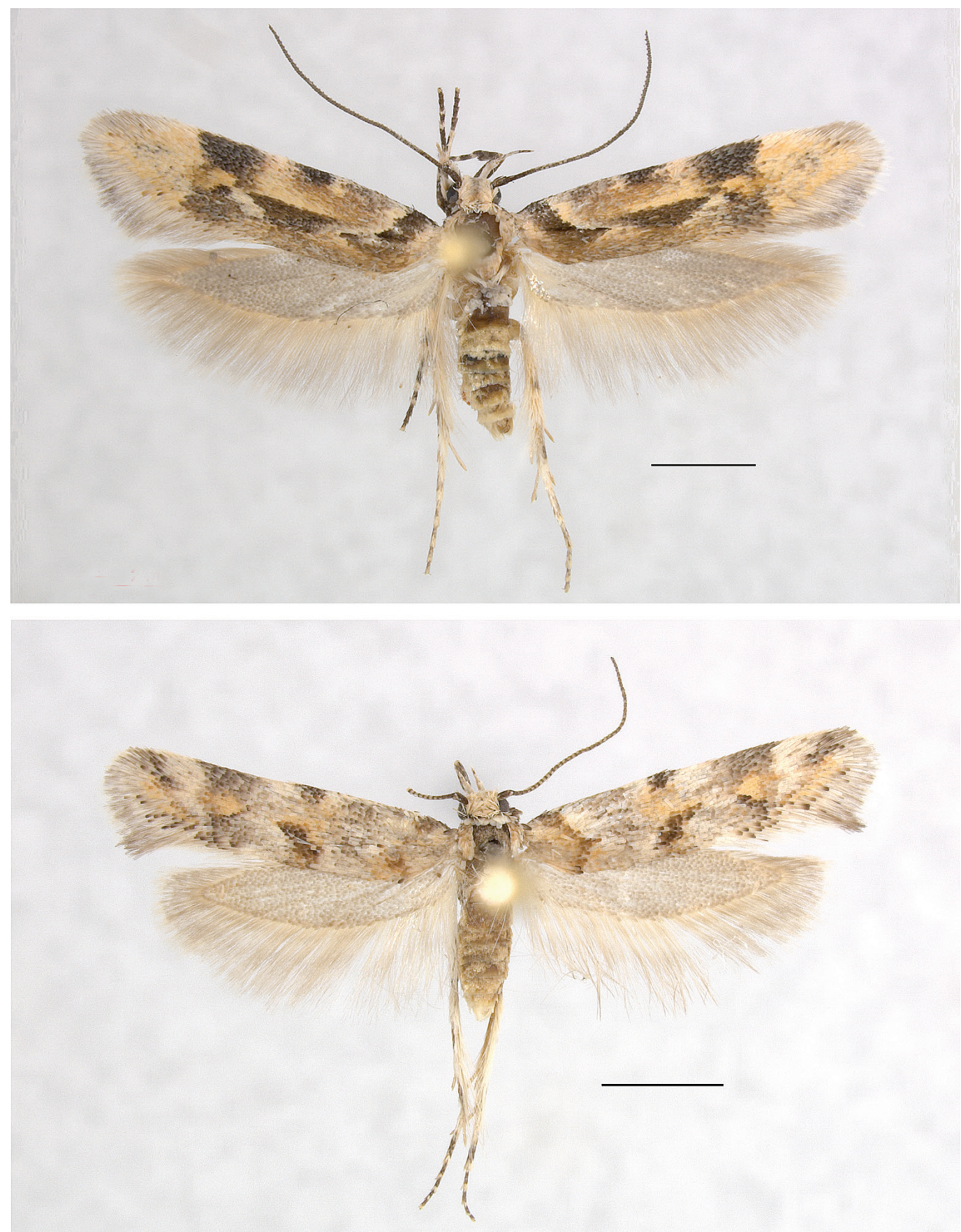

Figures 3, 4. Alloclita species, adult habitus. 3 A canariensis sp. nov., female paratype, Fuerteventura, Lajares, RMNH.INS 15579. 4 A. francoeuriae, male, Fuerteventura, Calderata, RMNH.INS 15580. Scale bars: $2 \mathrm{~mm}$. 
Diagnosis. Alloclita canariensis resembles A. francoeuriae and A. subitariella. It can be distinguished by the two blackish brown streaks on the forewing; the proximal streak bends upwards before it reaches the dorsum, the distal streak is broad and straight in the middle of the fold. In the male genitalia it differs from A. francoeuriae by the longer and more slender basal lobes of the valva and the longer and more slender cucullus. From A. subitariella it differs by the basally more slender brachia of the uncus and by the slender and apically rounded right basal lobe of the valva. In the female genitalia it differs from $A$. francoeuriae by the V-shaped anterior edge of segment VIII, by the more irregular shape of the sclerotized band of the ostium and by the narrower signa.

Description. Male and female (Figs 1-3). Forewing length 6.2-8.1 mm. Head: frons, vertex, neck tufts shining creamy white, collar dorsally shining creamy white, laterally shining dark brown; labial palpus first segment short, dark brown, about one-third length of second, second segment about as long as third, white with dark brown spot at base on outside, third segment white mixed with dark greyish, more white dorsally in basal half; scape dark greyish brown with pecten with two to three piliform scales, antenna dorsally dark greyish brown, ventrally white or annulated brownish grey in basal half, apical half slightly serrate. Thorax shining creamy white, tegulae shining dark brown anteriorly, shining creamy white posteriorly. Legs: foreleg dark brownish grey with white apical rings on tibia and first tarsal segment, midleg as foreleg but with additional broad white central band on tibia, hindleg femur white mixed with brownish grey, tibia basal two-thirds white with dark brown streak in middle on outer side, apical one-third dark greyish brown with white apical ring, tarsal segments dark greyish brown, first segment with broad basal and apical white rings, segments two to five with white apical rings, spurs white, apically ochreous-white. Forewing creamy white, two blackish brown streaks, proximal streak broad, semi-circular bend from costa beyond base to one-sixth, not reaching dorsum, distal streak longitudinal triangular in middle of fold at one-third; four brownish grey spots, first, counting from wing base, and smallest spot on costa at one-thirds of wing, second and largest spot, more or less square, on costa at two-thirds, third spot somewhat triangular, on dorsum at two-thirds, costal edge dorsally with blackish brown scales, fourth spot somewhat triangular on costa near tip of wing; apex on dorsal side edged blackish brown; dorsally below blackish brown streaks, in middle and at tip of wing creamy white areas more or less suffused with pinkish to orange scales; fringe dark grey at costa, creamy white to dorsum, pure white at tip of wing, broad dark grey fringe line in middle of fringe. Hindwing shining grey with greenish and reddish reflection, fringe grey with reddish gloss. Underside: forewing shining brownish grey with narrow whitish streaks on costa at onehalf, three-quarters and at tip of wing; hindwing shining grey. Abdomen dorsally and ventrally creamy white; anal tuft creamy white.

Variation. The creamy white ground colour of the forewing is often darkened to a greater or lesser extent.

Male genitalia (Fig. 6). Brachia of uncus long and slightly bent ventrally, right brachium a little shorter and wider beyond one-half, both brachia with small apical hook; tegumen short and broad, slightly tapering distally, half-length of brachia of uncus; valvae short with very wide base, tapering to short and rounded cucullus with long setae, right cucullus slightly narrower than left one; basal lobes of valvae of similar length, right basal lobe rounded apically, left basal lobe with apical 


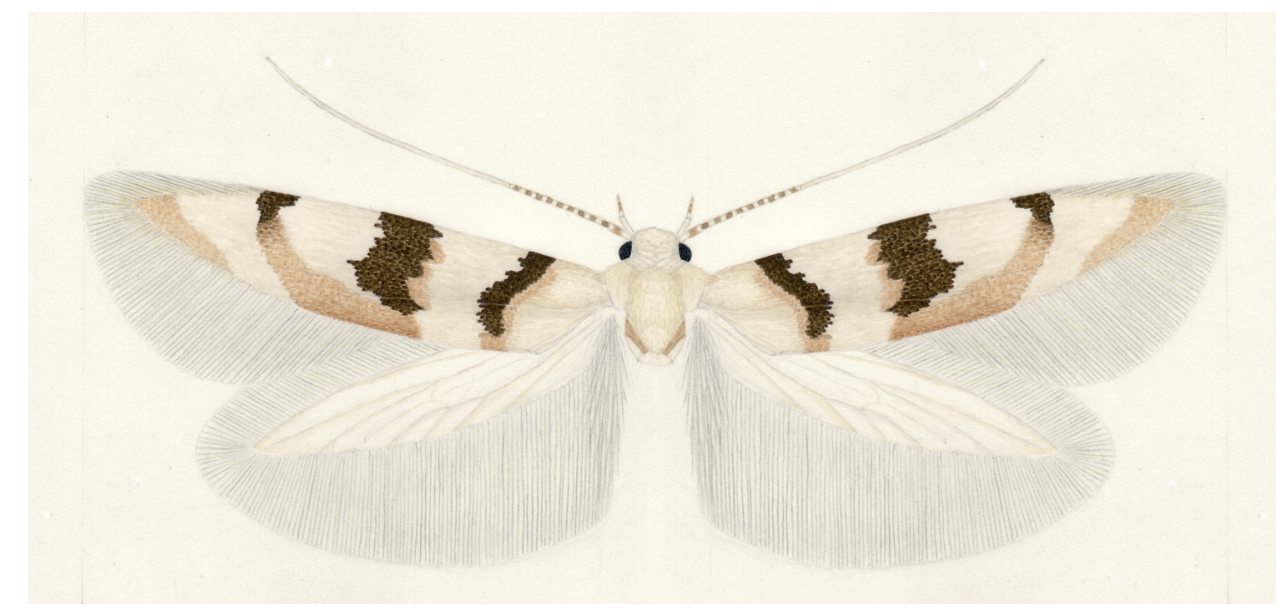

Figure 5. Alloclita subitariella, male habitus, Holotype, Saudi Arabia. Forewing length $5.1 \mathrm{~mm}$. The left wings are a mirror image of the right wings.

hook; anellar tube very broad at base, with triangular protrusions arising halfway along both sides, right protrusion twice as large as left one, distal half of anellar tube strongly tapering and with very short setae; manica slightly tapering distally, basal half strongly bent ventrally; phallus long and twisted; vinculum large, tapering distally and rounded.

Female genitalia (Fig. 11). Apophyses posteriores one-third longer than apophyses anteriores; segment VIII dorsally with two V-shaped anterior lobes; ostium with irregular sclerotized ventral band, right side twice as wide as left side; ductus bursae narrow in posterior third, anterior twothirds strongly widening towards corpus bursae and helical; corpus bursae oval, signa as two narrow rims with spicules.

Distribution (Figs 17, 18). Canary Islands: Fuerteventura, Gran Canaria, Lanzarote and Tenerife. Most likely an endemic species.

Biology. The specimens from Inagua on Gran Canaria were collected at light by Jari Junnilainen on the road side of GC-200. The light source was positioned near a spot where Asteriscus graveolens subsp. stenophyllus (Link) Greuter (Asteraceae) (Figs 15, 16) was dominant (previously known as Nauplius stenophyllus). The genus Asteriscus has a number of species occurring on the Canary Islands, partly endemic, partly also occurring on the African mainland (Goertzen et al. 2002). They occur on all islands where Alloclita canariensis was found (Hohenester and Welß 1993; Bramwell and Bramwell 2001). The fact that Asteriscus is related to Pulicaria and the abundant occurrence on the Gran Canaria locality make Asteriscus a likely candidate hostplant.

Adults found from early November to March, in May and September; adults may fly year-round.

DNA barcodes (Fig. 19). From four specimens from the islands Fuerteventura, Gran Canaria and Tenerife we obtained full-length DNA barcodes. All barcodes fall within Barcode Index Number (BIN) BOLD:ADR0826. The intraspecific distance is $0.31-1.86 \%$ (mean $1.18 \pm 0.75, \mathrm{n}=6$ ), the largest distance between specimens from Tenerife and both other islands, the distance between the Fuerteventura specimen and both Gran Canaria specimens is $0.46-0.77 \%$, and between the Gran Canaria specimens $0.3 \%$. The distance to nearest neighbour $A$. francoeuriae is $3.86 \%$ (mean $4.115 \pm 0.44, \mathrm{n}=9)$. 


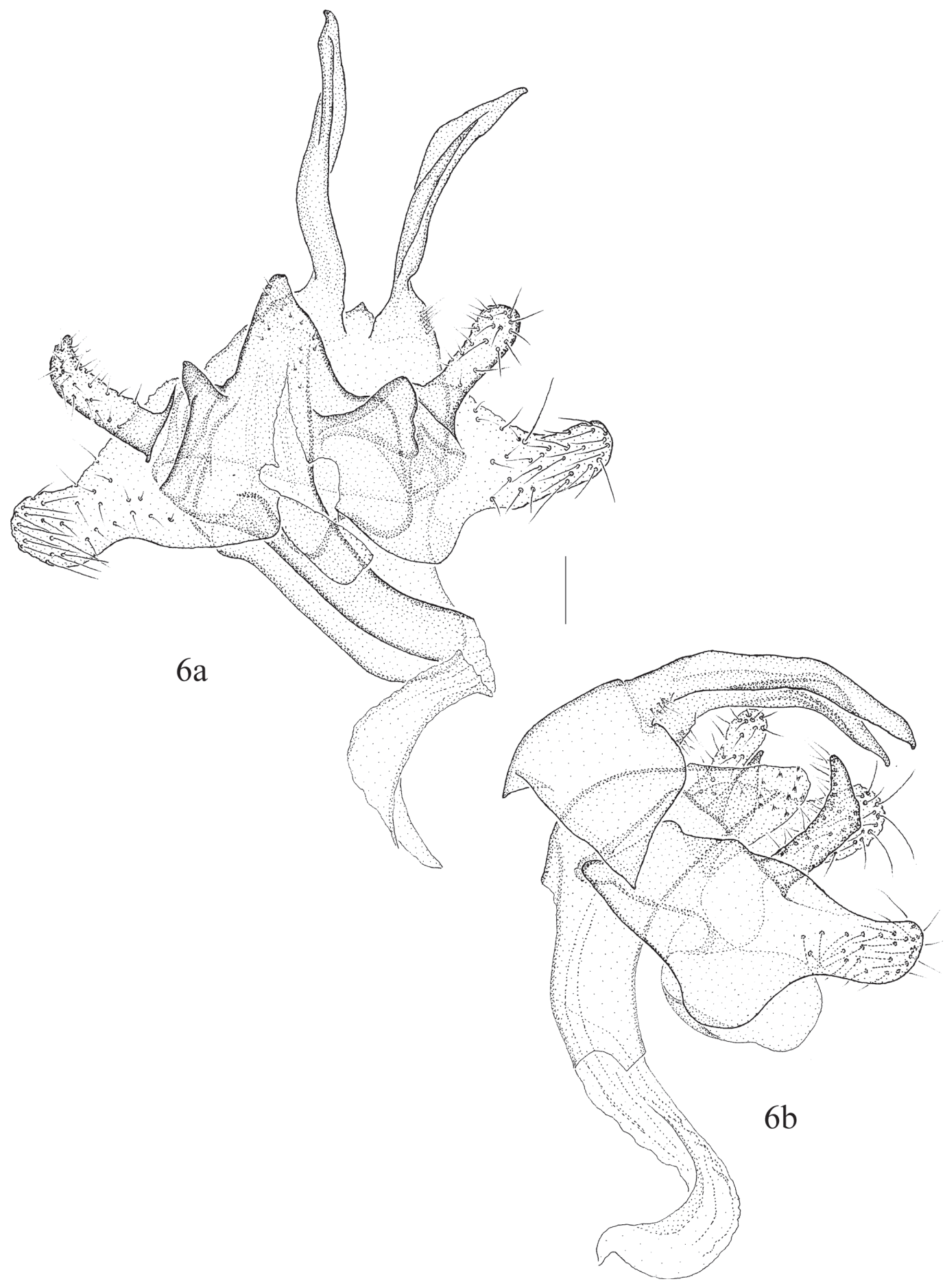

Figure 6. Alloclita canariensis sp. nov., male genitalia, paratypes. 6a ventral aspect, genitalia slide JCK 8675 6b lateral aspect, genitalia slide JCK 8679 . Scale bar: $0.1 \mathrm{~mm}$. 


\section{Alloclita francoeuriae Walsingham, 1905}

Figs 4, 7, 12, 17-19

Alloclita francoeuriae Walsingham, 1905: 126.

Alloclita francoeuriae; Sinev 1993: 134 [review]; Koster and Sinev 2003: 102 [redescription]

Allocrita francoeuriae; Rungs 1979: 61 [record Morocco] [misspelling]

Material examined. Syntypes. Algeria • 1 ð̊; Biskra; $34.86^{\circ} \mathrm{N}, 5.73^{\circ} \mathrm{E} ; 23 \mathrm{Feb} .1895$; [Eaton leg.]; Walsingham 96473 leg.; Walsingham Collection B.M. 1910-427; Genitalia not dissected; NHMUK • 1 q; "Hammam-es-Salahin" [Hammam Salihine]; $34.857^{\circ} \mathrm{N}, 5.70819^{\circ} \mathrm{E}$; Apr. 1903; larva on Pulicaria undulata; emerged 18 Jul. 1903; Walsingham 96451 leg.; Walsingham Collection B.M. 1910-427; genitalia slide: BM 29280; NMMUK.

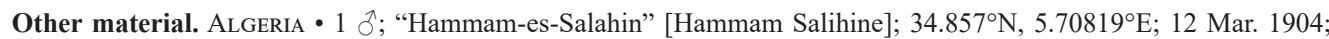
Walsingham 97937 leg.; Walsingham Collection B.M. 1910-427; NHMUK・ 1 §; same locality as preceding; 6 Apr. 1904; Walsingham 97943 leg.; Walsingham Collection B.M. 1910-427; genitalia slide: BM 29279; NHMUK.

Morocco • 1 ふै; Guelmim-Oued Noun: Sidi Ifni; $29.38333^{\circ} \mathrm{N} 10.1725^{\circ} \mathrm{W}$; alt. sea level; 5-7 Mar. 2017; C. Hviid, O. Karsholt, K. Larsen, D. Nilsson leg.; genitalia slide: JCK 8689; DNA barcode sample COSM069-18; ZMUC; RMNH. INS. 15581

SPAIN • 1 §; Canary Islands, Fuerteventura, Calderata; $28.59^{\circ} \mathrm{N}, 13.88^{\circ} \mathrm{W}$; alt. $120 \mathrm{~m}$; 7-27 Nov. 2017; P. Falck leg.;

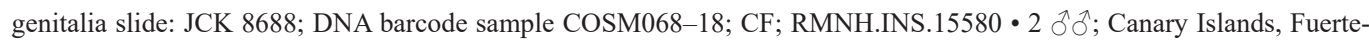
ventura, Betancuria; $28.425^{\circ} \mathrm{N}, 14.057^{\circ} \mathrm{W}$; alt. 400 m; 7-27 Nov. 2017; P. Falck leg.; CF.

Other localities (material examined by S. Yu Sinev, personal communication). AlgERIA $\bullet$ Beni Ounif; $32.05^{\circ} \mathrm{N}, 1.25^{\circ} \mathrm{W}$; - El Golea; $30.559^{\circ} \mathrm{N}, 2.887^{\circ} \mathrm{E}$.

Morocco • Ademine (nr Ain Nekhla); $30.318^{\circ} \mathrm{N}, 9.356^{\circ} \mathrm{W} \cdot$ Ait Melloul; $30.34^{\circ} \mathrm{N}, 9.5^{\circ} \mathrm{W}$.

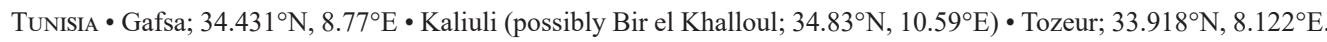

Diagnosis. Alloclita francoeuriae can be distinguished from A. canariensis and A. subitariella by the proximal dark brown streak of the forewing which reaches dorsum, and by the distal dark brown streak above fold which has a basal extension towards dorsum (Fig. 4). In the male genitalia (Fig. 7) it differs from A. canariensis by the shorter basal lobe of the valva and by shorter and broader cucullus. It differs from $A$. subitariella by the rounded tip of the right lobe of the valva and by the short shallow protrusions arising halfway along the anellar tube. In the female genitalia (Fig. 12) it differs from A. canariensis by the very shallow rounded anterior edge of segment VIII, by the band-shaped sclerotization of the ostium and by the sheet-shaped sclerotization of the signum.

Distribution (Figs 17, 18). Algeria, Tunisia, Morocco (Koster and Sinev 2003), Spain: Canary Islands: Fuerteventura (new record). In northern Africa along the northern border of the Sahara.

Biology. Larva in April burrowing under the woolly bark of Pulicaria undulata (Asteraceae), after eating out the inside of the leaves it makes sand galleries attached to the crown of the root. Pupa pale brown, in a dense white cocoon, covered with sand and frass particles (Walsingham 1905). Pulicaria undulata and other species of Pulicaria are also known from Fuerteventura (Hohenester and Welß 1993).

Adults from the end of February to early April, in July (Koster and Sinev 2003) and November.

DNA barcodes (Fig. 19). We barcoded one specimen from Fuerteventura and one from Morocco. Both share BIN BOLD:ADR0547. The intraspecific distance between the two is only $0.16 \%$. 


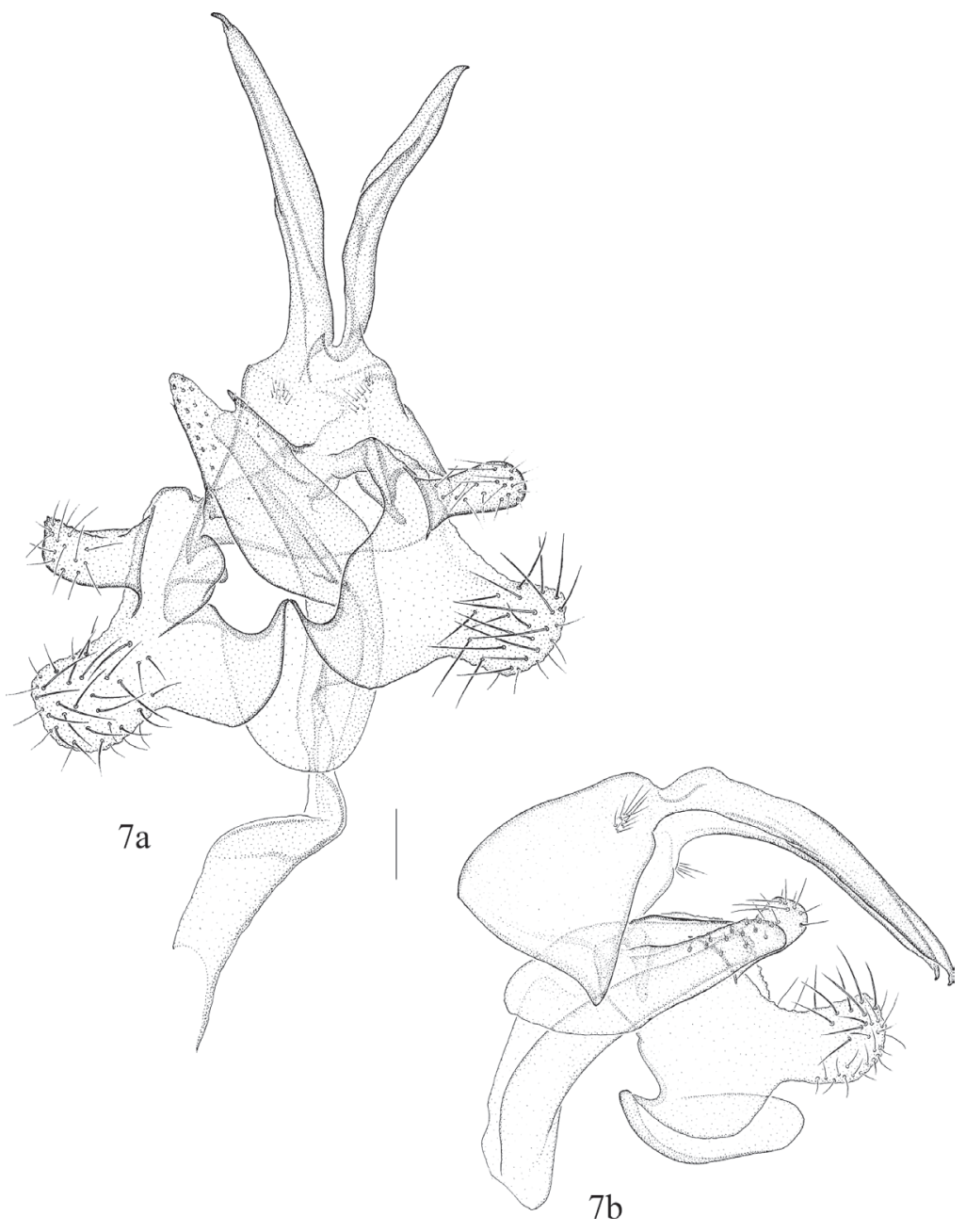

Figure 7. Alloclita francoeuriae, male genitalia, BM 29279. 7a ventral aspect 7b lateral aspect. Scale bar: $0.1 \mathrm{~mm}$.

Remarks. Walsingham (1905) cited a male and a female type, these are thus syntypes, and other original material does not belong to the type series (ICZN Art. 72.4.6, International Commission on Zoological Nomenclature 1999). We do not see a need to select either syntype as lectotype.

\section{Alloclita subitariella (Riedl, 1993)}

Figs 5, 8, 18

Proceleustis subitariella Riedl, 1993: 149.

Alloclita subitariella (Riedl, 1993): Sinev 2002: 40 [recombination].

Material examined. Holotype. SAUdi Arabia • $1 \delta^{\jmath}$; Maraba; $17.9^{\circ} \mathrm{N}, 42.38^{\circ} \mathrm{E} ; 3$ Sep. [19]78; W. Saenger leg.; genitalia slide: 1310/R; NHMB. 

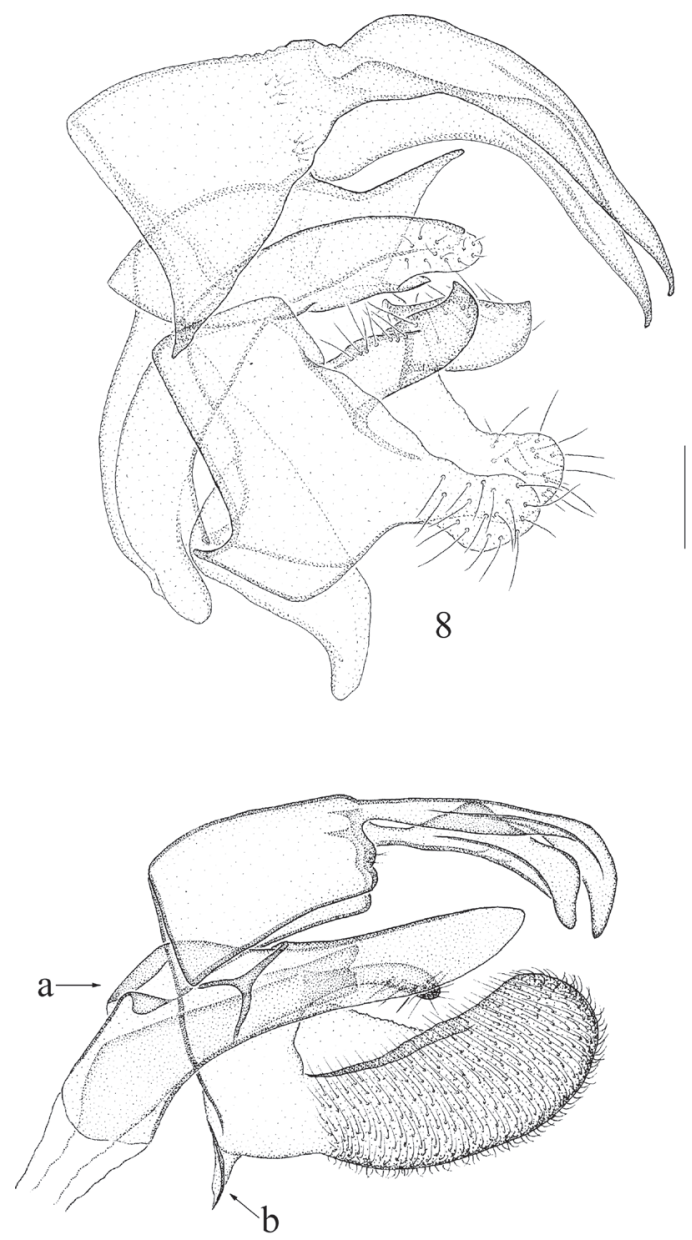

9

Figures 8, 9. Alloclita species, male genitalia. 8 A. subitariella, holotype, lateral aspect, genitalia slide 1310/R 9 A. recisella, lateral aspect; a. manica; $\mathbf{b}$. vinculum. Scale bar: $0.1 \mathrm{~mm}$.

Diagnosis. Alloclita subitariella can be distinguished from A. canariensis and A. francoeuriae by the proximal blackish brown streak on the forewing as an incomplete fascia which does not reach the dorsum and by the distal blackish brown streak that runs as a very broad fascia from the costa but does not reach the dorsum. In the male genitalia it differs from $A$. canariensis and $A$. francoeuriae by the broad-based brachia of the uncus and by the basal lobes of the valvae both of which bear an apical hook.

Redescription. Male (Fig. 5). Forewing length $5.1 \mathrm{~mm}$. Head: frons, vertex, neck tufts and collar shining white; labial palpus white, first segment short, less than half of the length of the second, second segment about as long as third with a brown dorsal spot at base, third segment with a broad, pale brown ring in apical half, apex white; scape dorsally white with a brown spot in middle, ventrally white, antenna white, annulated brownish grey, apical two-thirds missing. Thorax and tegulae shining creamy white. Legs: femora of fore and midleg white with some greyish brown irroration 


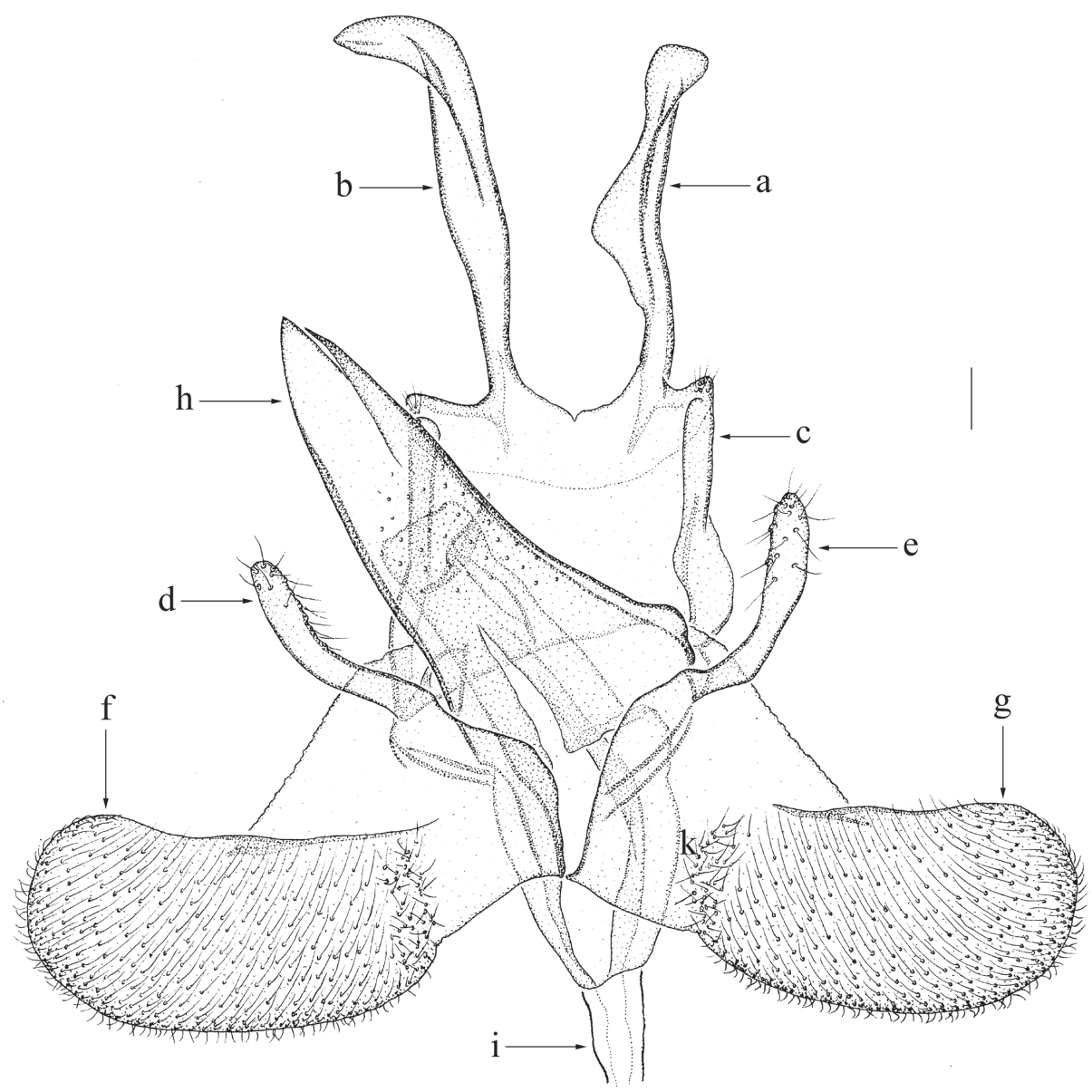

Figure 10. Alloclita recisella, male genitalia, ventral aspect, genitalia slide JCK 5256 a right brachium of uncus $\mathbf{b}$ left brachium of uncus $\mathbf{c}$ tegumen $\mathbf{d}$ left basal lobe $\mathbf{e}$ right basal lobe $\mathbf{f}$ left valva $\mathbf{g}$ right valva $\mathbf{h}$ anellar tube i phallus. Scale bar: $0.1 \mathrm{~mm}$.

in apical half, tibiae and tarsi dark greyish brown, foreleg tibia with white basal, medial and apical rings, tarsal segment one with white basal and apical ring, segment two with white apical ring, segments three to five entirely dark greyish brown, midleg tibia as in foreleg, but medial ring twice as wide, tarsal segments one to three as in foreleg, segments four and five missing, hindlegs missing, spurs white. Forewing creamy white, at one-fifth a dark brown, outward oblique, fascia, below fold bending towards dorsum but not reaching it, outer edge irregular and at inner side edged pale ochreous, this edging runs to dorsum, at two fifths a dark brown fascia, twice as broad as inner one, not reaching dorsum and both inner and outer edge very irregular, at inner side edged pale ochreous from below costa to dorsum, at four-fifths a dark brown costal spot, prolonged towards dorsum as an inward oblique pale ochreous fascia, connected to the dorsal edging of the second fascia, a broad pale ochreous streak from tip of wing almost to tornus, fringe line indistinct, fringe creamy white. Hindwing shining white, fringe creamy white. Underside: forewing shining pale ochreous, dark brown fasciae indistinct; hindwing shining white. Abdomen not examined, already dissected. 


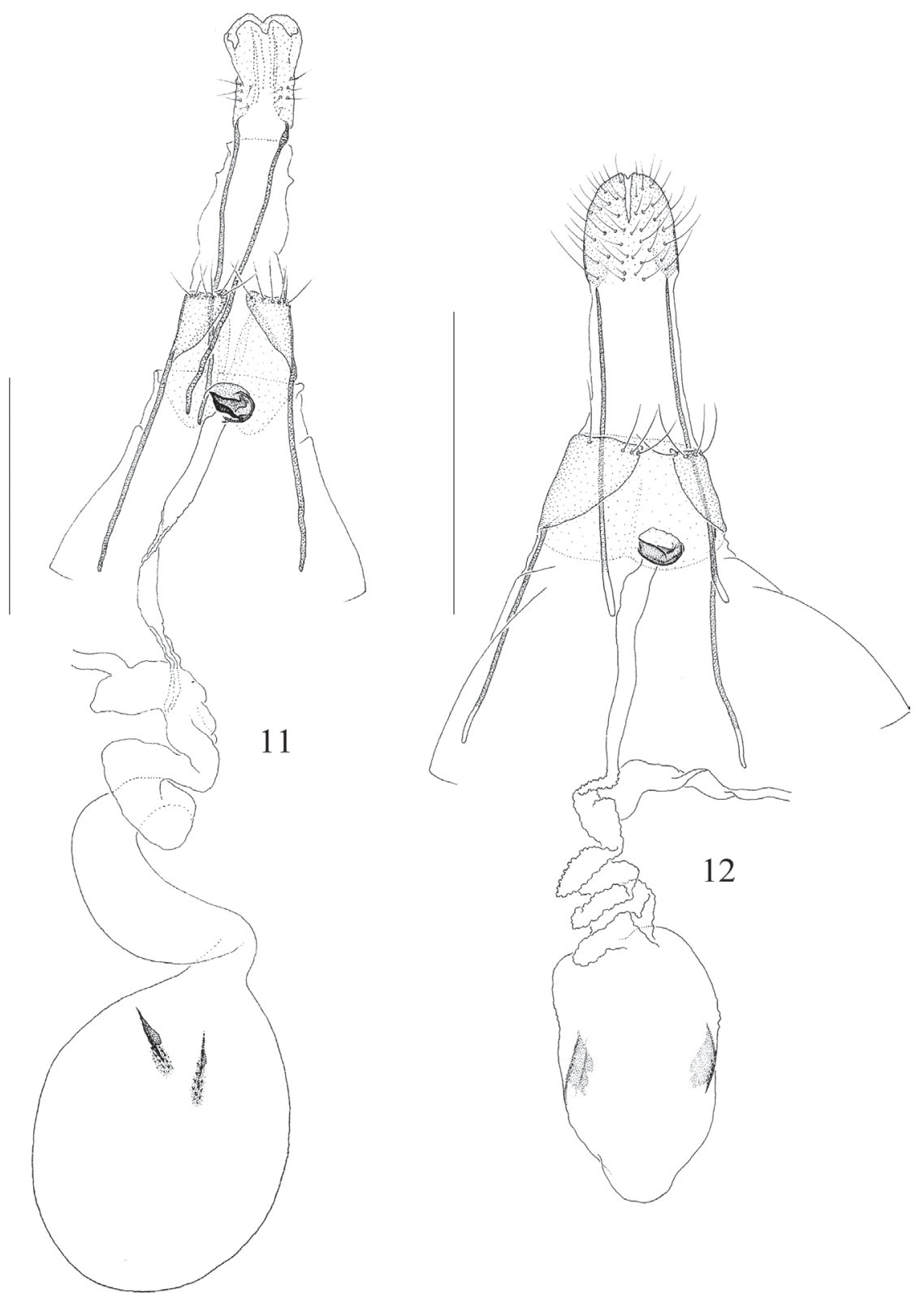

Figures 11, 12. Alloclita species, female genitalia. 11 A. canariensis sp. nov., paratype, ventral aspect, genitalia slide JCK 867812 A. francoeuriae, syntype, ventral aspect, genitalia slide BM 29280. Scale bars: $1 \mathrm{~mm}$.

Male genitalia (Fig. 8). Brachia of uncus long and slightly bent ventrally, both brachia of equal length and wide at base, right brachium slightly more bent and more narrowed before middle, both brachia with small apical hook; tegumen short, broad and strongly tapering distally, halflength of brachia of uncus; valvae short with very wide base, tapering to short and rounded cucullus with long setae, right cucullus slightly wider than left one; basal lobes of valvae of unequal length, right 

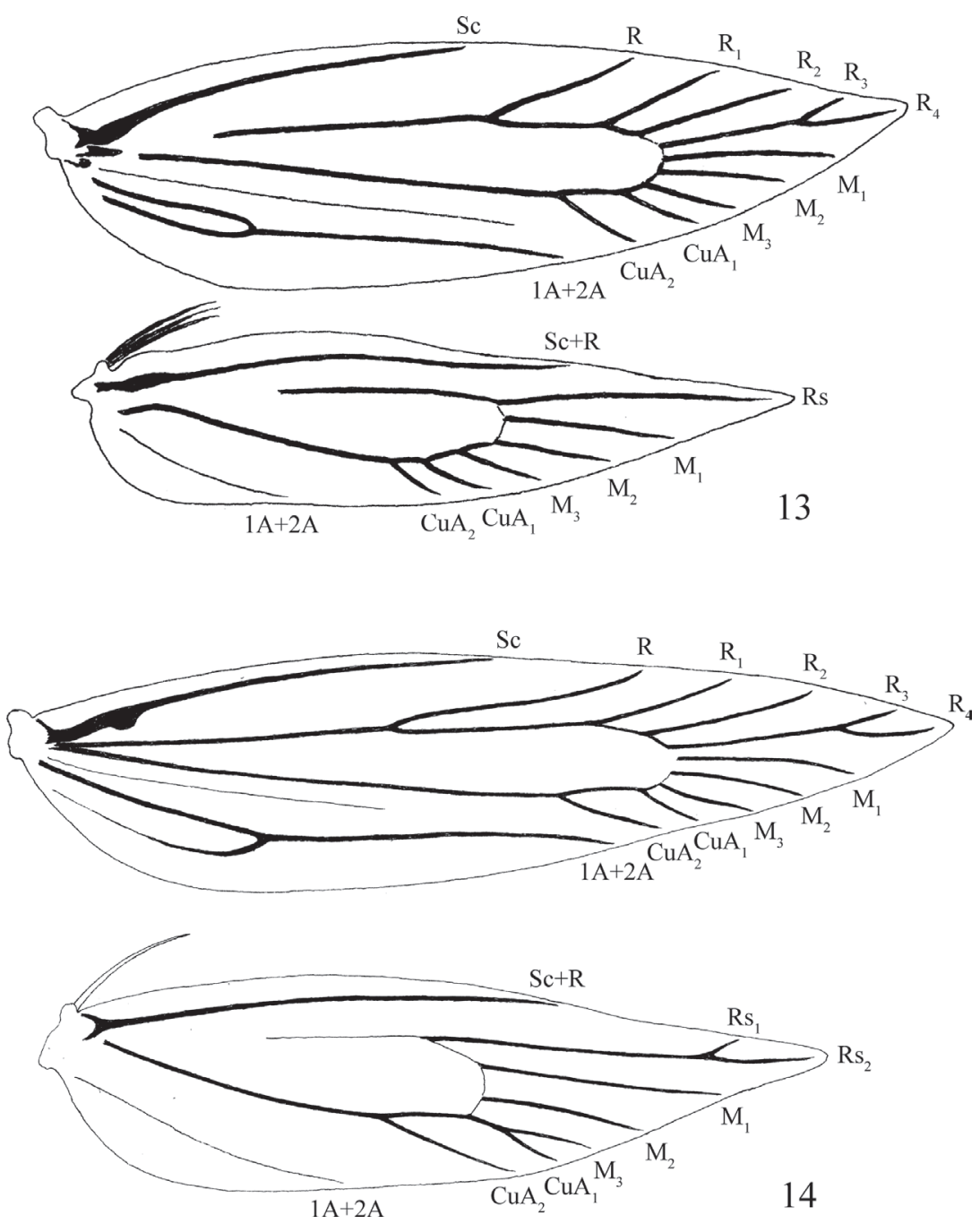

Figures 13, 14. Alloclita species, wing venation. 13 A. recisella-species group: A. delozona, wing slide JCK 869114 A. francoeuriae-species group: A. canariensis, wing slide JCK 8690.

basal lobe slightly wider than left one and with blunt apical hook, left basal lobe a quarter longer than the length of the right lobe and with a sharp apical hook; anellar tube very broad at base, with large triangular and pointed protrusion halfway along right side and shallow triangular protrusions halfway along right side, distal half of anellar tube strongly tapering and with very short setae; manica slightly widening towards base and strongly bent ventrally; phallus long, bent and tapering distally; vinculum large and bent downwards in middle.

Distribution (Fig. 18). Saudi Arabia (Riedl 1993).

Biology. Unknown. The holotype was collected in early September.

Remarks. The single specimen is in poor condition. The male genitalia are positioned laterally on the slide with the phallus in situ and do not show all the characters properly. 


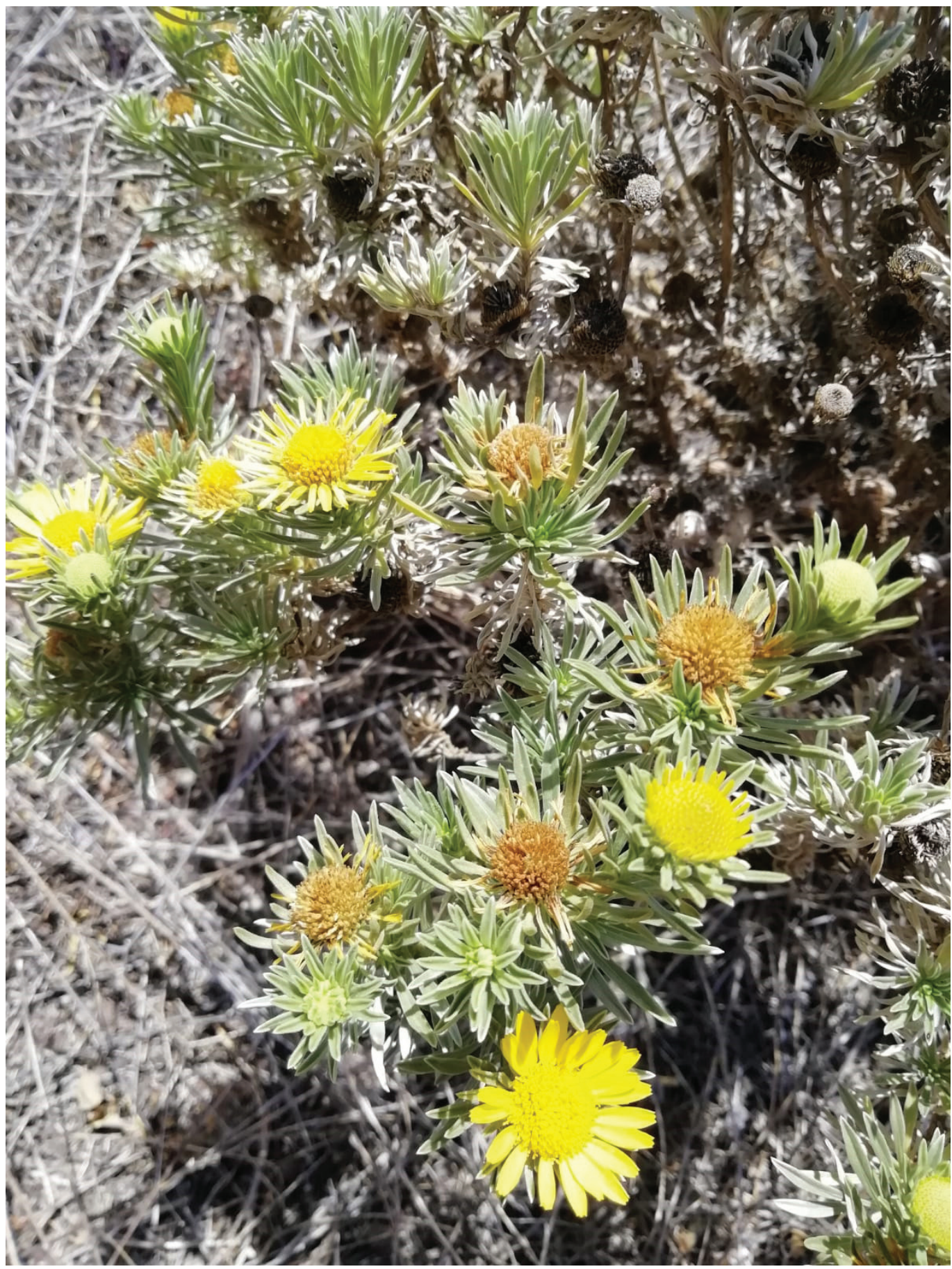

Figure 15. Asteriscus graveolens subsp. stenophyllus at the collecting site Inagua on Gran Canaria, the possible hostplant of Alloclita canariensis sp. nov. Photo Jukka Tabell. 


\section{Discussion}

Given that only two specimens of Alloclita canariensis were collected earlier (1930 and 1931, Vives Moreno and Gastón 2017), it is remarkable that Alloclita canariensis has been found recently in such large numbers over a period of just a few years and also on as many as four of the seven main Canary Islands. While this finding may be related to the increasing activity of collectors of Microlepidoptera, it is curious that most of the previous collectors did not collect this relatively large and attractively coloured species.

\section{Taxonomy}

Koster and Sinev (2003) mentioned the longer and narrower forewings of $A$. francoeuriae and the difference in the male genitalia compared to other species of the genus. The wing venation of $A$. recisella was depicted by Riedl (1969) under the generic name Dharania Amsel, 1958, a junior synonym of Alloclita. The wing venation of $A$. francoeuriae has not been illustrated before, although Walsingham (1905) provides a brief description of the venation of the fore- and the hindwing. Checking the wing venation of Alloclita delozona Meyrick, 1919 (Fig. 13) and A. cerritella (Riedl, 1993) in the recisella group showed these to be the same as Riedl's figure of $A$. recisella. The venation of the forewing of $A$. francoeuriae and $A$. canariensis (Fig. 14) hardly differs from that of the $A$. recisella group, just most of the veins are longer, which is due to the longer and narrower forewing. The differences between these two groups of species are in the hindwings. The veins in the hindwings of the A. recisella species-group each originate from the cell individually. In the hindwings of the $A$. francoeuriae species-group, Rs splits before the tip of the wing into $\mathrm{Rs}_{1}$ and $\mathrm{Rs}_{2}$, and $\mathrm{M}_{1}$ and $\mathrm{CuA}_{1}$ are joined from the base to about one-half. The wing venation of $A$. subitariella has not been examined.

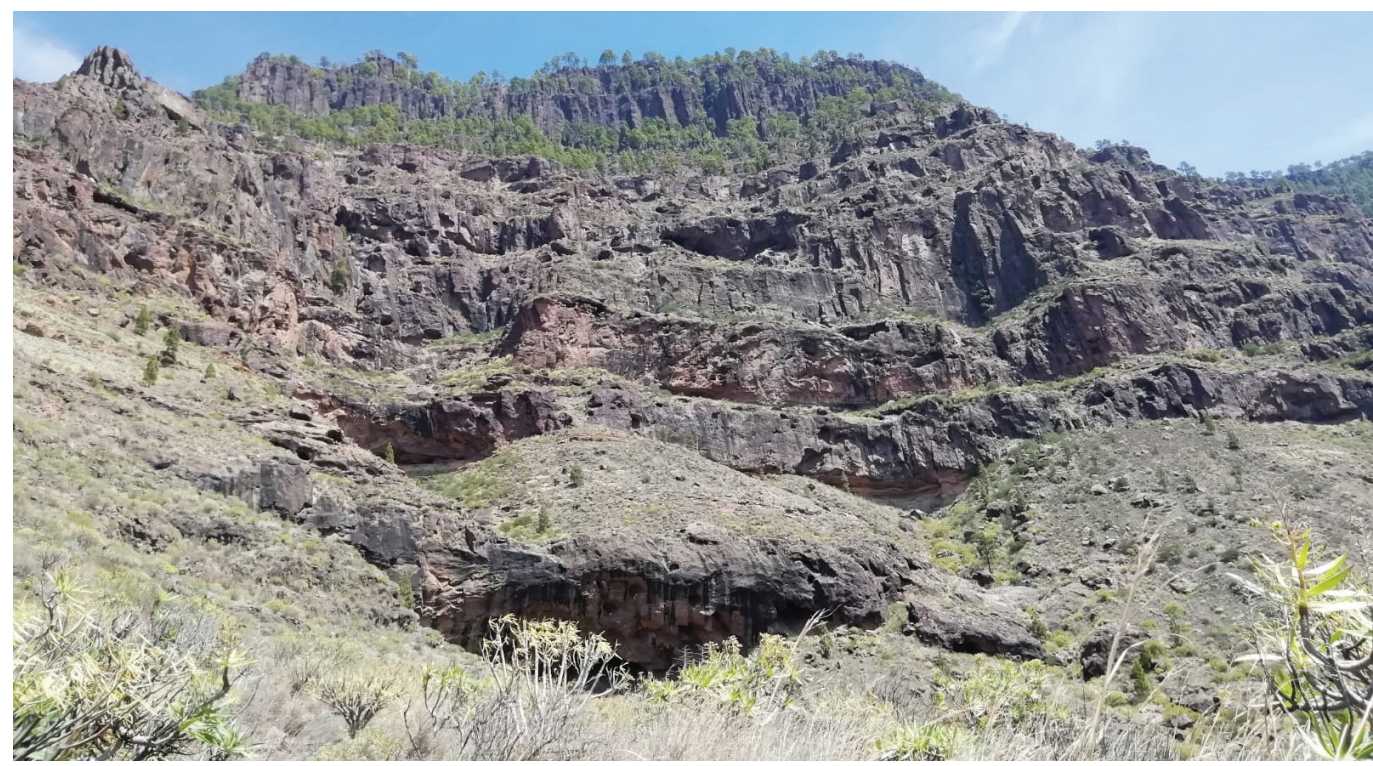

Figure 16. Collecting site of Alloclita canariensis sp. nov. at Inagua, Gran Canaria. Photo Jukka Tabell. 


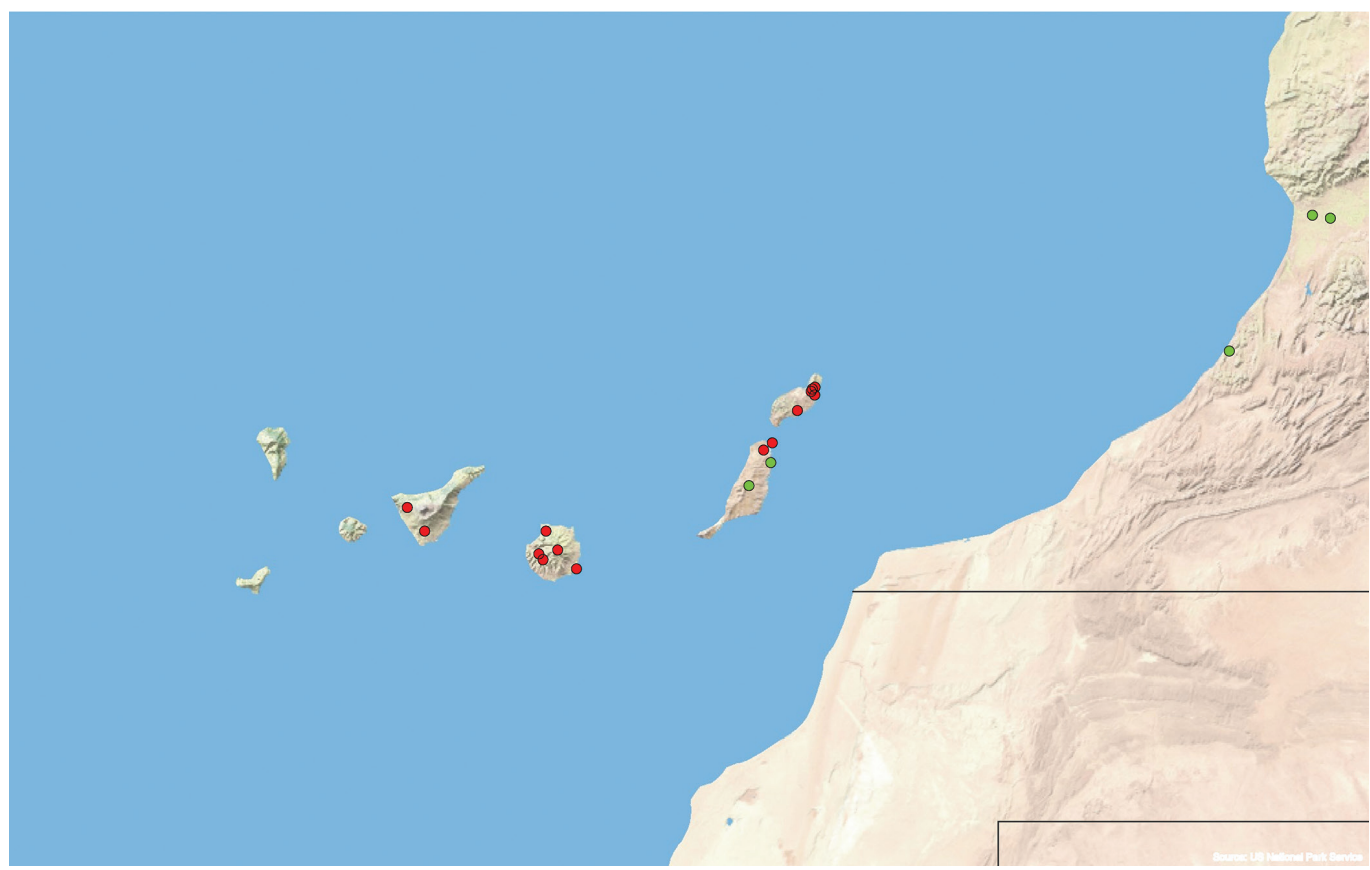

Figure 17. Map showing records of Alloclita canariensis sp. nov. and A. francoeuriae on the Canary Islands and nearby Morocco. Red circles: A. canariensis, green circles: A. francoeuriae.

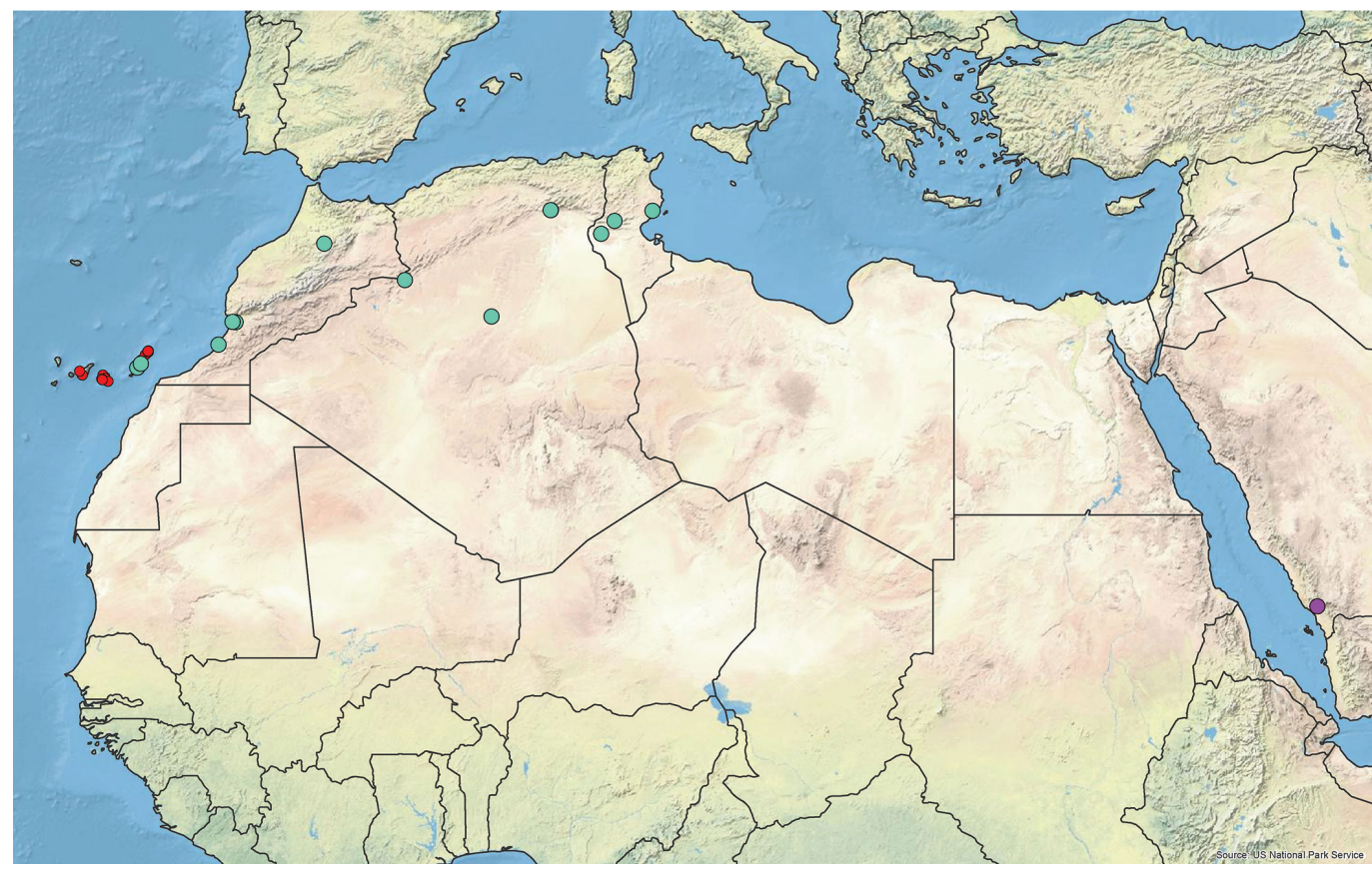

Figure 18. Map showing records of the Alloclita francoeuriae group. Red circles: A. canariensis, green circles: A. francoeuriae, purple circle $A$. subitariella. 
In the male genitalia there are also differences between these two species groups. The male genitalia of the $A$. recisella-group (Figs 9, 10) are symmetrical except for the brachia of the uncus. The right brachium (Fig. 10a) is shorter and strongly broadened from one-half; the left brachium (Fig. 10b) is longer, more slender and with a bent tip. The tegumen is broad, almost square or slightly tapering distally. The valva (Fig. 10f, g) is broad at its base with rather long, parallel-sided, heavily setose and distally rounded cucullus. The vinculum (Fig. 9b) is rounded and narrow to rather broad. Near the base of each valva is a club-shaped basal lobe (Fig. 10d, e) with a length of one-quarter to one-half the length of the valva. Two large and tapering anellus-lobes are fused to form an anellar tube (Fig. 10h). Inside the anellar tube the manica (Fig. 9a) is long and bent downwards. The phallus (Fig. 10i) is long and without cornuti. The male genitalia of the A. francoeuriae-group (Figs 6-8) are more asymmetrical than those of the $A$. recisella-group. The differences can be found in the following: both brachia of the uncus differ slightly in length and shape, but less so than in the $A$. recisella- group. The tegumen narrows distally. The valvae are broad at the base, but taper strongly to a small and rounded cucullus with fewer, but larger, setae, and both valvae differ slightly in shape. The vinculum is large, rounded and more prominent. The basal lobes of the valvae are short and broad and differ slightly in length and shape. The anellar tube is generally shorter and broader at its base.

In the female genitalia the differences are less prominent: the only difference found between the species-groups is the helical shape of the anterior two-thirds of the ductus bursae.

\section{DNA barcoding}

DNA barcoding (Fig. 19). The barcode of Alloclita canariensis is distinct, but exhibits considerable intraspecific variation between the populations of the various islands. The sample is too small for far reaching conclusions, but it seems that each island has one or more separate haplotypes, suggesting some isolation between populations. The barcodes of the $A$. francoeuriae from Fuerteventura and Morocco are so similar that it seems likely that specimens from Morocco colonised Fuerteventura. This is probably a common scenario as Fuerteventura and Lanzarote share more species with continental northern Africa than the more western islands, while these have more endemic species than the eastern islands (Báez and Oromi 2010; Falck and Karsholt 2019a, 2019b).

Both species group together in the Neighbor Joining tree (Fig. 19). All seven included species have distinct DNA barcodes.

\section{Acknowledgements}

We are grateful to Sergey Sinev and Vladimir Lukhtanov (ZIN, St. Petersburg, Russia) for allowing us to use DNA barcodes of three Alloclita species from their projects and Sergey Sinev also for information on localities of A. francoeuriae. We thank Jukka Tabell (Hartola, Finland) for the photographs of the potential food plant and the collecting site in Inagua, Gran Canaria. Frank Stokvis (Naturalis, Leiden, Netherlands) is thanked for sequencing work. David Lees (NHMUK, London, UK) is thanked for providing information on the genitalia slides in the type series of Alloclita francoeuriae. Ole Karsholt thanks Carsten Hviid, Knud Larsen, Danny Nilsson and Bjarne Skule (all Denmark) for collecting specimens for ZMUC. Vazrick Nazari (Ottawa, Canada), Jan Šumpich (Prague, Czech Republic) and Daniel Rubinoff (Honolulu, USA) are acknowledged for their comments on the manuscript. 


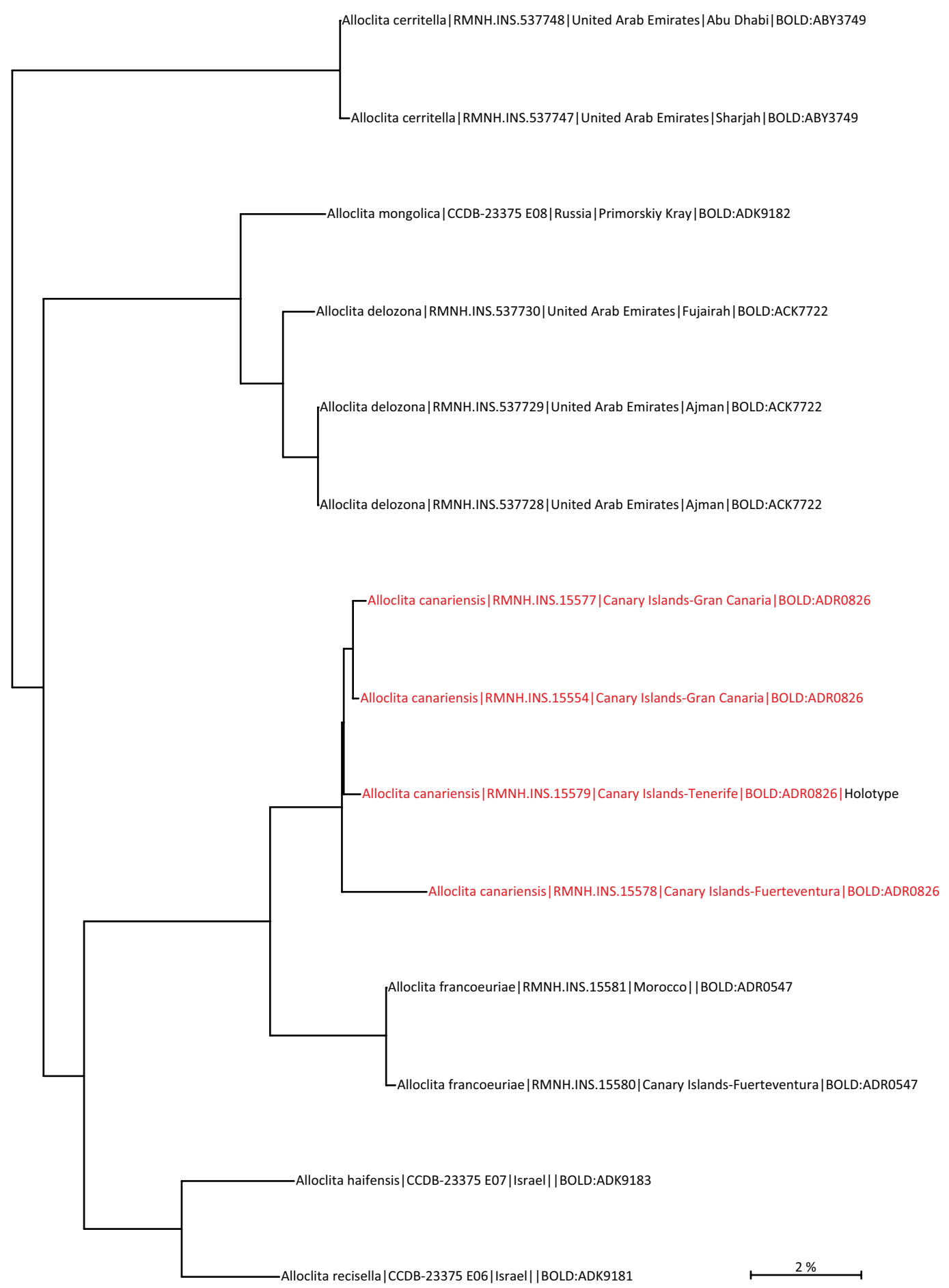

Figure 19. Neighbor Joining tree of DNA barcodes of seven species of Alloclita. 


\section{References}

Báez M, Oromi P (2010) Orden Lepidoptera. In: Arechavaleta Hernández M, Rodríguez Núñez S, Zurita Pérez N, García Ramírez A (Eds) Lista de Especies Silvestres de Canarias. Hongos, Plantas y Animales Terrestres. Gobierno de Canarias, Santa Cruz de Tenerife: 302-318. http://www.gobiernodecanarias.org/ medioambiente/piac/descargas/Biodiversidad/Listas-Especies/Lista_Especies_Silvestres.pdf

Bramwell D, Bramwell ZI (2001) Wild Flowers of the Canary Islands (2 $2^{\text {nd }}$ edn.). Editorial Rueda, Madrid, 437 pp.

Brown PA (1997) A review of techniques used in the preparation, curation and conservation of microscope slides at the Natural History Museum, London. Biology Curator 10: 1-34. http://www.natsca.org/article $/ 455$

Doorenweerd C, Nieukerken EJ van, Menken SBJ (2015) A global phylogeny of leafmining Ectoedemia moths (Lepidoptera: Nepticulidae): exploring host plant family shifts and allopatry as drivers of speciation PloS ONE 10: e0119586. https://doi.org/10.1371/journal.pone.0119586

Falck P, Karsholt O (2019a) New data on Praydidae, Oecophoridae, Stathmopodidae, Scythrididae and Cosmopterigidae from the Canary Islands, Spain (Insecta: Lepidoptera). SHILAP Revista de Lepidopterologica 47(186): 325-340.

Falck P, Karsholt O (2019b) The Ethmia terminella group from the Canary Islands (Spain) and Morocco (Lepidoptera: Depressariidae, Ethmiinae). SHILAP Revista de Lepidopterologica 47(188): 641-649.

Goertzen LR, Francisco-Ortega J, Santos-Guerra A, Mower JP, Linder CR, Jansen RK (2002) Molecular systematics of the Asteriscus Alliance (Asteraceae: Inuleae) II: Combined Nuclear and Chloroplast Data. Systematic Botany 27: 815-823. http://www.jstor.org/stable/3093926

Hodges RW (1978) Gelechioidea, Cosmopterigidae. In: Dominick RB, Ferguson DC (Eds) The Moths of America North of Mexico 6.1 E.W. Classey, London, 166 pp. [6 pls.]

Hodges RW (1998) Gelechioidea. In: Kristensen NP (Ed.) Lepidoptera: Moths and Butterflies 1. Evolution, Systematics and Biogeography. Handbuch der Zoologie/Handbook of Zoology 4(35), Walter de Gruyter, Berlin \& New York, 491 pp.

Hohenester A, Welß W (1993) Exkursionsflora für die Kanarischen Inseln: mit Ausblicken auf ganz Makaronesien. E. Ulmer, Stuttgart: 374 pp. [24 plates]

International Commission on Zoological Nomenclature (1999) International Code of Zoological Nomenclature. Fourth edition. Adopted by the International Union of Biological Sciences. The International Trust for Zoological Nomenclature, London, 306 pp. [with amendments 2012] https://www.iczn.org/the-code/ the-international-code-of-zoological-nomenclature/the-code-online/

Koster JC (2016) The genus Cosmopterix Hübner of continental Sub-Saharan Africa (Lepidoptera: Gelechioidea: Cosmopterigidae). Tijdschrift voor Entomologie 158: 87-318. https://doi.org/10.1163/2211943415802002

Koster JC (2019) The illustrating of Microlepidoptera in color and the genitalia apparatus in black and white line drawings. I.N.G.A, Newsletter of the International Network of Gelechioid Aficionados 8: 8-16. https://mississippientomologicalmuseum.org.msstate.edu/Researchtaxapages/Lepidoptera/Gelechioidea/ INGA/INGA_issues/I.N.G.A._8_2019.pdf

Koster JC, Sinev SY (2003) Momphidae, Batrachedridae, Stathmopodidae, Agonoxenidae, Cosmopterigidae, Chrysopeleiidae. Apollo Books, Stenstrup, Microlepidoptera of Europe 5: 1-387.

Koster JC, Sinev SY (2017) Batrachedridae, Cosmopterigidae, Momphidae, Stathmopodidae. In: Karsholt O, Nieukerken EJ van (Eds) Fauna Europaea: Lepidoptera. Fauna Europaea version 2017.06. https://fauna-eu.org/

Meyrick E (1919) Exotic Microlepidoptera. Volume 2(8): 225-256. https://biodiversitylibrary.org/ page/9808621 
Nieukerken EJ van, Doorenweerd C, Stokvis FR, Groenenberg DSJ (2012) DNA barcoding of the leaf-mining moth subgenus Ectoedemia s. str. (Lepidoptera: Nepticulidae) with COI and EF1- $\alpha$ : two are better than one in recognising cryptic species. Contributions to Zoology 81: 1-24. https://doi.org/10.1163/18759866-08101001

Ratnasingham S, Hebert PDN (2007) BOLD: The Barcode of Life Data System (www.barcodinglife.org). Molecular Ecology Notes 7: 355-364. https://doi.org/10.1111/j.1471-8286.2007.01678.x

Riedl T (1969) Matériaux pour la connaissance des Momphidae paléarctiques (Lepidoptera), 9. Revue des Momphidae européennes, y compris quelques espèces d'Afrique du Nord et du Proche-Orient. Polskie Pismo entomologiczne 39(4): 635-919.

Riedl T (1993) Cosmopterigidae and Chrysopeleiidae (Lepidoptera) from Saudi Arabia, and a concise catalogue of the species of the genus Proceleustis Meyrick. Fauna of Saudi Arabia 13: 144-151.

Robinson GS (1976) The preparation of slides of Lepidoptera genitalia with special reference to the Microlepidoptera. Entomologist's Gazette 27: 127-132. http://idtools.org/id/leps/tortai/Robinson_1976.pdf

Rungs CEE (1979) Catalogue raisonné des Lépidoptères du Maroc. Inventaire faunistique et observations écologiques, 1. Travaux de l'Institut Scientifique Chérifien, Série Zoologique 39: 1-222. [A221-A225]

Sinev SY (1993) Kratkij obzor roda Alloclita Stgr. (Lepidoptera, Cosmopterigidae) s opisaniem novogo vida iz Mongolii. [A brief review of the genus Alloclita Stgr. (Lepidoptera, Cosmopterigidae) with description of a new species from Mongolia]. Trudy Zoologicheskogo Instituta 248: 132-138. [In Russian]

Sinev SY (2002) World catalogue of cosmopterigid moths (Lepidoptera: Cosmopterigidae). Katalog roskoshnykh uzkokrylykh molej (Lepidoptera: Cosmopterigidae) mirovoj fauny. Trudy Zoologicheskogo Instituta 293: 1-184.

Staudinger O (1859) Diagnosen nebst kurze Beschreibung neuer andalusischer Lepidopteren. Stettiner entomologische Zeitung 20(7-9): 211-259.

Vives Moreno A, Gastón J (2017) Contribución al conocimiento de los Microlepidoptera de España, con la descripción de una especie nueva (Insecta: Lepidoptera). SHILAP Revista de Lepidopterología 45(178): 317-342. http://www.redalyc.org/articulo.oa?id=45551614016

Walsingham T (1905) Algerian Microlepidoptera. Entomologist's monthly Magazine 41: 124-128. https:// biodiversitylibrary.org/page/9015849

\section{Supplementary material 1}

\section{Table S1}

Authors: Sjaak (J.C.) Koster, Per Falck, Jari Junnilainen, Ole Karsholt, Erik J. van Nieukerken

Data type: specimen data

Copyright notice: This dataset is made available under the Open Database License (http://opendatacommons.org/licenses/odbl/1.0/). The Open Database License (ODbL) is a license agreement intended to allow users to freely share, modify, and use this Dataset while maintaining this same freedom for others, provided that the original source and author(s) are credited.

Link: https://doi.org/10.3897/nl.43.48404.suppl1 